\title{
Value-Based Pricing for Emerging Gene Therapies: The Economic Case for a Higher Cost-Effectiveness Threshold
}

\author{
Louis P. Garrison, PhD; Tristen Jackson, PharmD, MS; \\ Douglas Paul, PharmD, PhD; and Mike Kenston, BS, MBA
}

\begin{abstract}
SUMMARY
While one-time gene replacement therapies may offer transformative innovation for the management of ultrarare, health-catastrophic diseases, they also pose challenges to the current U.S. health care system. Historically, the United States and other countries have demonstrated a willingness to support higher prices for health gains in rare diseases. However, payers may be ill-prepared to address reimbursement based on single administrations associated with gene therapies. As yet, there is no consensus on how to appropriately reward gene therapy innovation. The purpose of this article is to characterize challenges for traditional approaches to assessing the value of one-time gene replacement therapies and to provide a health economic rationale for a higher value-based cost-effectiveness threshold (CET).

There is a general recognition that ultrarare, health-catastrophic conditions should be judged against a higher CET. The Institute for Clinical and Economic Review in the United States has discussed a range of up to $\$ 500 \mathrm{~K}$ per quality-adjusted life-year (QALY) gained for ultrarare diseases, and the National Institute for Health and Care Excellence in the United Kingdom has described a variable threshold up to $£ 300,000$ per QALY depending on the magnitude of the health gains. In practice, health technology assessment decision makers often make comparisons to "benchmarks" to justify both standard and extraordinary CETs. We briefly review and present a list of relevant benchmarks.

We also sketch out how a broader concept of value could provide the basis for higher CETs for some ultrarare diseases. This approach is outlined by the recent International Society for Pharmacoeconomics and Outcomes Research Special Task Force on Value Assessment Frameworks. In addition to the QALY gains, other elements of value related to uncertainty may also be important. They include insurance value, severity of disease, real option value, value of hope, and equity.
\end{abstract}

A gene therapy currently in development for the treatment of spinal muscular atrophy (SMA) provides an exemplar for discussing the issues that accompany one-time gene replacement therapies. It is imperative that we find a consensus on how to appropriately reward value created by these gene therapies to incentivize appropriate risk taking and investments by their developers-a higher CET would, by economic logic, support a higher value-based price. If consensus on appropriate rewards cannot be found for safe and effective gene therapies for diseases such as SMA with clear criticality and unmet need, it will be even more difficult to do so for diseases where the value provided is less apparent.

J Manag Care Spec Pharm. 2019;25(7):793-99

Copyright @2019, Academy of Managed Care Pharmacy. All rights reserved. he development of one-time gene replacement therapies for ultrarare, health-catastrophic diseases heralds a new era of transformative innovation that may offer cures (or near cures) while reducing the high lifetime cost of medicines administered chronically. The United States and other countries have adopted regulations and incentives to encourage the development of orphan products for rare diseases and have, in practice, demonstrated some willingness to pay higher prices for these health gains compared with those for more common diseases. Although there is some concern that the package of incentives is excessive, here we examine the economic case for supporting a higher value-based cost-effectiveness threshold (CET) as an incentive. ${ }^{1}$

One-time dosing with potential lifetime benefit creates challenges for payers to adequately reward the manufacturers of such innovations with a sufficient return on their investment. Traditionally, the assessed value and financing of pharmaceutical therapies have been heavily influenced by the duration of treatment. Economic value is generally defined in terms of health gained (i.e., quality-adjusted life-years [QALY]) plus cost-offsets assessed over the time horizon of impact. However, assigning appropriate value over the long run for one-time gene replacement therapies is difficult because this usually requires extrapolation from small trials of short duration. In addition, the annual budget cycle of health plans with limited resources for their populations creates a financing challenge. To date, plans often focus on budget impact rather than value, and no clear consensus has emerged on how to address these issues as several gene therapies are looming on the horizon. ${ }^{2}$

The purpose of this short Viewpoints article is to characterize the challenges for traditional approaches to assessing the value of one-time gene replacement therapies and to provide a health economic rationale for a higher value-based CET.

\section{Approaches to CETs for Ultrarare,}

\section{Health-Catastrophic Conditions}

Why use CETs in the first place? The simplest rationale is that health care decision makers will want to maximize the benefits from their fixed annual budget, following the basic microeconomic principle of comparing marginal benefit and marginal cost. This comparison yields the incremental cost-effectiveness ratio as used in health technology assessment (HTA). As a general rule in a market economy, the value of an economic good can be viewed in 2 ways: what individuals are willing to pay 
for it (a demand-side view) or what they have to trade off to get it (an opportunity cost or supply-side view). ${ }^{3}$ Since the bulk of health care is financed by insurance, it is difficult to ascertain either of these directly. In this section, we briefly review some of the issues and approaches to establishing QALY-based CETs. Then, we sketch out how a broader concept of value could provide the basis for a higher CET for some ultrarare diseases.

In practice, HTA decision makers often make comparisons to benchmarks (Table 1) to justify standard and extraordinary CETs. These benchmarks can be decision rules established by HTA bodies, standards generated by alternative methodologies, or comparisons with previous analog technologies. Historically, kidney hemodialysis set a benchmark 35 years ago based on its average annual cost of $\$ 50 \mathrm{~K}$, which has arguably had a perverse effect on the history of the CET. ${ }^{4-7}$ Absent dialysis, chronic renal failure patients would die. By providing extensive Medicare coverage for these patients, we expressed a societal preference to buy life-years at this price. To this day, a \$50K CET (i.e., cost-per-QALY benchmark) is used as a lower bound. ${ }^{8}$ However, given the average utility for hemodialysis patients of about 0.6, the implied CET was about $\$ 83 \mathrm{~K}$ per QALY in 1980 (in 1980 U.S. dollars). ${ }^{9}$ Today, hemodialysis averages about $\$ 89 \mathrm{~K}$ annually for nearly 500,000 patients, implying a CET of about $\$ 148 \mathrm{~K}$ per QALY. ${ }^{10}$

The Institute for Clinical and Economic Review (ICER) in the United States is an increasingly influential, private, nonprofit HTA body offering free publicized assessments on newly approved medicines. ICER has used a CET range of $\$ 50 \mathrm{~K}$ per QALY to $\$ 150 \mathrm{~K}$ per QALY for common conditions, but it does not provide a specific or unique numerical derivation; rather, it cites a variety of approaches that fall in this range. ${ }^{8}$ Approaches vary from quantified economic theory to an often-cited, WHO-endorsed aspirational threshold of 1-3 times per capita gross domestic product (GDP) for low- and middle-income countries. ${ }^{11,12}$ The basis for the latter is unclear and has been questioned, but it has had a considerable effect on policy discussions. ${ }^{13}$ Per capita GDP in the United States was $\$ 59,500$ in 2017, so the implied high end of ICER's range (at \$150K CET) is $19 \%$ below this. ${ }^{14}$

This demand-side approach has been questioned by U.K. researchers taking an empirical, opportunity-cost approach. They estimated, for example, that the U.K. health system can produce an additional QALY for $£ 12,936 .{ }^{15,16}$ They ask: Why should they pay more than this for innovations? U.K. GDP per capita was about $\$ 39,700$ ( $£ 30,300$ ) in $2017 .{ }^{14}$ The National Institute for Health and Care Excellence's (NICE) initial threshold of $£ 30 \mathrm{~K}$ per QALY was gradually revised down to about £20K per QALY. ${ }^{15}$

Although there is currently no consensus on whether coverage and pricing of new treatments for ultrarare, healthcatastrophic conditions should be judged against a higher CET, there is at least a general recognition this may well be the case. ICER has discussed a range of up to $\$ 500 \mathrm{~K}$ per QALY for ultra- rare diseases but has said it will still publicize the base-case value-based price (VBP) at a CET of $\$ 150 \mathrm{~K}$ per QALY gained. ${ }^{17}$ NICE has defined these as "highly specialized technologies" that should be subject to a much higher, but variable threshold up to $£ 300 \mathrm{~K}(\$ 390 \mathrm{~K})$ per QALY depending on the magnitude of the QALY gains. ${ }^{18}$

If a therapy "cures" a disease that would be fatal in early childhood, an additional question emerges about the value of a full life. Societal value-of-life benchmarks come from a variety of sources (Table 1). Prominent among these is the large amount of literature on the value of a statistical life (VSL). ${ }^{19,20}$ Some of these are "revealed preference" studies, reflecting a wide range of real-world situations where individuals make choices that involve some trade-off between mortality risk and moneyfor example, higher wages for work in a risky occupation. In "stated preference" studies, individuals are asked hypothetically how much they would be willing to pay to avoid a small mortality risk. A recent comprehensive review summarizing 4 meta-analyses found an overall range of the VSL of $\$ 2 \mathrm{M}$ to \$11.1M (2009 U.S. dollars).$^{19}$ In an earlier meta-analysis, Hirth et al. (2000) compared 42 VSL studies relying on different approaches (e.g., human capital vs. revealed preference) and found a range of medians from \$25K to \$428K (in 1997 U.S. dollars). ${ }^{4}$ Various U.S. government agencies use these estimates in benefit-cost analyses of proposed regulations or projects. ${ }^{21}$ In a 2016 analysis, the U.S. Department of Health and Human Services projected that in 2018-after discounting to adjust for the time value of money and accounting for the growth in real incomes-the VSL would range from $\$ 4.6 \mathrm{M}$ to $\$ 15.0 \mathrm{M}$ with a central estimate of $\$ 9.9 \mathrm{M}$ (2014 U.S. dollars). ${ }^{22}$ Also in 2016, the U.S. Department of Transportation recommended a mean VSL of $\$ 9.6 \mathrm{M}$ with a range from $\$ 5.4 \mathrm{M}$ to $\$ 13.4 \mathrm{M}$ (2015 U.S. dollars) for these evaluations. ${ }^{23}$ Since mean nominal life expectancy was about 78.8 years in 2014, which translates to about 30.5 years (when discounted at 3\% per annum), this implies about \$315K per life-year. Despite the use of these VSL estimates in regulatory analyses, there remains an ongoing discussion about potential upward bias because of publication and parameter selection bias or the difference between willingness to accept versus willingness to pay for mortality risks. ${ }^{24,25}$

The literature also makes an important distinction between identifiable lives and statistical lives, which are not identifiable. The Rule of Rescue has been defined as "the moral imperative to rescue identified individuals in immediate peril, regardless of cost." ${ }^{26}$ Might this also suggest a similar willingness to rescue individuals in ultrarare, health-catastrophic situations?

Another approach to thinking about CETs for ultrarare, health-catastrophic conditions is to compare with the cost of other drugs and procedures (Table 1). For example, ICER calculated lifetime cost estimates or incremental cost-effective ratios for several "high-cost" orphan or ultrarare conditions, including emicizumab prophylaxis in hemophilia A (\$21M for 
TABLE 1 Estimates and Sources Relevant to CETs

\begin{tabular}{|c|c|c|c|}
\hline $\begin{array}{l}\text { HTA Body, Methodology, or } \\
\text { Technology }\end{array}$ & $\begin{array}{c}\text { Relevant Utility and } \\
\text { Cost-Effectiveness Estimates }\end{array}$ & $\begin{array}{c}\text { Implied CET or Incremental } \\
\text { Cost-Effectiveness Ratio }\end{array}$ & Sources \\
\hline \multicolumn{4}{|l|}{ HTA body/government agency } \\
\hline ICER consensus range & $\begin{array}{l}\text { \$50K-150K for non-orphans } \\
\$ 175 \mathrm{k}-\$ 500 \mathrm{k} \text { for ultra-orphans }\end{array}$ & $\begin{array}{l}\text { \$175K-\$500K per } \\
\text { QALY for ultraorphans }\end{array}$ & ICER (January 2018; 2017)8,17 \\
\hline Value of a statistical life (U.S. HHS) & $\begin{array}{l}\text { Central: \$9.9M; range: } \$ 4.6 \mathrm{M}-\$ 15.0 \mathrm{M} \\
\text { (2014 USD) }\end{array}$ & \$328K per QALY & $\operatorname{ASPE}(2016)^{22}$ \\
\hline Value of a statistical life (U.S. DOT) & $\begin{array}{l}\text { Mean: \$9.6M; range: } \$ 5.4 \mathrm{M}-\$ 13.4 \mathrm{M} \\
(2015 \text { USD) }\end{array}$ & $\$ 315 \mathrm{~K}$ per QALY & Moran and Monje (2016)23 \\
\hline NICE range & $\begin{array}{l}£ 20 \mathrm{~K}-£ 300 \mathrm{~K} \text { for highly specialized } \\
\text { technologies }\end{array}$ & $\$ 390 \mathrm{~K}$ per QALY & NICE $(2017)^{18}$ \\
\hline \multicolumn{4}{|l|}{ Methodological approaches } \\
\hline $\begin{array}{l}\text { Value of a statistical life (systematic } \\
\text { literature review) }\end{array}$ & Midpoint: $\$ 6.5 \mathrm{M} ; \$ 2 \mathrm{M}$ to $\$ 11.1 \mathrm{M}$ per life & $\$ 213 \mathrm{~K}$ per LY & Bosworth et al. (2017) \\
\hline $\begin{array}{l}\text { Value of a statistical life (systematic } \\
\text { review and quantitative analysis) }\end{array}$ & $\begin{array}{l}\text { Included human capital, contingent } \\
\text { valuation, and revealed preference studies }\end{array}$ & \begin{tabular}{|l|} 
\$25K-\$428K (medians) across \\
study types (1997 USD)
\end{tabular} & Hirth et al. $(2000)^{4}$ \\
\hline Welfare economics theory & 2 times per capita GDP & \$119K per QALY & Garber and Phelps (1997)11 \\
\hline Opportunity-cost approach & $\begin{array}{l}£ 13 \mathrm{~K} \text { (in relation to U.K. GDP per capita } \\
\text { of } £ 39.7 \mathrm{~K} \text { ) }\end{array}$ & $\$ 20 \mathrm{~K}$ per QALY & $\begin{array}{l}\text { Claxton et al. (2013)15; Woods et al. } \\
(2016)^{16}\end{array}$ \\
\hline Expert consensus & 1-3 times per capita GDP & \$60K-\$179K per QALY & WHO $(2001)^{12}$ \\
\hline $\begin{array}{l}\text { Rule of rescue for nonmedical } \\
\text { identified lives }\end{array}$ & Thousands and millions & NA & Cookson $(2017)^{26}$ \\
\hline \multicolumn{4}{|l|}{ Specific health technologies } \\
\hline $\begin{array}{l}\text { Hemodialysis for end-stage renal } \\
\text { disease }\end{array}$ & $\begin{array}{l}\text { Utility on dialysis: } 0.6 \\
\text { 1980: Average cost per year: } \$ 50 \mathrm{~K} \\
\text { Implied CET: } \$ 83 \mathrm{~K} \\
\text { 2016: Average cost per year: } \$ 89 \mathrm{~K} \\
\text { Implied CET: } \$ 148 \mathrm{~K}\end{array}$ & \$148K per QALY & $\begin{array}{l}\text { Authors' calculations; Grosse (2008)6; } \\
\text { Wyld }(2012)^{9} ; \text { U.S. Renal Data System } \\
(2017)^{10}\end{array}$ \\
\hline $\begin{array}{l}\text { Hemophilia A with bypassing } \\
\text { agents }\end{array}$ & $\begin{array}{l}\text { For patients aged }<12 \text { years, discounted } \\
\text { lifetime costs and QALYs: } \\
\text { No prophylaxis: } \$ 31 \mathrm{M}, 20.40 \text { QALYs } \\
\text { BPA prophylaxis: } \$ 99 \mathrm{M}, 22.41 \text { QALYs } \\
\text { Emicizumab prophylaxis: } \$ 21 \mathrm{M}, 22.79 \text { QALYs }\end{array}$ & $\begin{array}{l}\text { \$39M per QALY } \\
\text { Cost-saving; dominant }\end{array}$ & ICER (April 2018) 27 \\
\hline $\begin{array}{l}\text { Inherited retinal disease- } \\
\text { voretigene neparvovec }\end{array}$ & $\begin{array}{l}\text { Drug wholesale acquisition cost: } \$ 855 \mathrm{~K} \\
\text { Average QALY gain: } 1.3 \text { (treatment age } 12 \text { ) } \\
\text { Icer: } \$ 644 \mathrm{~K} \text { per QALY }\end{array}$ & \$644K per QALY & ICER (February 2018)28 \\
\hline $\begin{array}{l}\text { Cystic fibrosis with gating } \\
\text { mutation-ivacaftor }\end{array}$ & $\begin{array}{l}\text { Total lifetime drug cost: } \$ 7.44 \mathrm{M} \\
\text { Average QALYs gain: } 6.73 \\
\text { Icer: } \$ 957 \mathrm{~K} \text { per QALY }\end{array}$ & \$957K per QALY & ICER (May 2018)29 \\
\hline $\begin{array}{l}\text { CAR-T therapy for B-cell acute } \\
\text { lymphoblastic leukemia }\end{array}$ & $\begin{array}{l}\text { Tisagenlecleucel (vs. clofarabine) } \\
\text { Total discounted lifetime cost: } \$ 667 \mathrm{~K} \\
\text { Total discounted QALYs gained: } 7.18 \\
\text { Icer: } \$ 46 \mathrm{~K} \text { per QALY } \\
\text { Axicabtagene ciloleucel (vs. chemotherapy) } \\
\text { Total discounted lifetime cost: } \$ 617 \mathrm{~K} \\
\text { Total discounted QALYs gained: } 3.40 \\
\text { Icer: } \$ 136 \mathrm{~K} \text { per QALY }\end{array}$ & \$136K per QALY & ICER (March 2018) 32 \\
\hline $\begin{array}{l}\mathrm{Cl} \text { esterase inhibitors for hereditary } \\
\text { angioedema }\end{array}$ & $\begin{array}{l}\text { No prophylaxis: } \$ 10.0 \mathrm{M}, 17.47 \text { QALYs } \\
\text { Cinryze: } \$ 14.4 \mathrm{M}, 18.21 \text { QALYs } \\
\text { Haegarda: } \$ 10.3 \mathrm{M}, 18.65 \text { QALYS }\end{array}$ & $\begin{array}{l}\text { Cinryze: } \$ 5.9 \mathrm{M} \text { per QALY } \\
\text { Haegarda: } \$ 328 \mathrm{~K} \text { per QALY }\end{array}$ & ICER (November 2018)30 \\
\hline $\begin{array}{l}\text { Nusinersen (Spinraza) for SMA } \\
\text { (type 1) }\end{array}$ & $\begin{array}{l}\text { Drug cost: } \$ 750 \mathrm{~K} \text { Year } 1 \text { and } \$ 375 \mathrm{~K} \text { annually } \\
\text { thereafter }\end{array}$ & $>\$ 375 \mathrm{~K}$ per QALY & Medi-Span $(2018)^{31}$ \\
\hline Organ transplants & $\begin{array}{l}\text { Estimated billed charges (2017; 5-year } \\
\text { survival): } \\
\text { - Heart: } \$ 1.38 \mathrm{M}(78 \%) \\
\text { - Liver: } \$ 813 \mathrm{~K}(75 \%) \\
\text { - Lung-double: } \$ 1.19 \mathrm{M}(55 \%) \\
\text { - Heart-lung: } \$ 2.53 \mathrm{M}(51 \%) \\
\end{array}$ & NA & Bentley and Phillips (2017) 33 \\
\hline
\end{tabular}

ASPE = Office of the Assistant Secretary for Planning and Evaluation; BPA=bypassing agent; CAR- $T=$ chimeric antigen receptor $T$-cell therapy; CET =cost-effectiveness threshold; DOT = Department of Transportation; GDP = gross domestic product; HHS=Department of Health and Human Services; HTA=health technology assessment; ICER = Institute for Clinical and Economic Review; Icer=incremental cost-effectiveness ratio; LY=life-year; NA=not available; NICE=National Institute for Health and Care Excellence; $Q A L Y=q u a l i t y$-adjusted life-year; SMA = spinal muscular atrophy; USD =U.S. dollars; WHO= World Health Organization. 


\section{FIGURE 1 Potential Elements of Value}

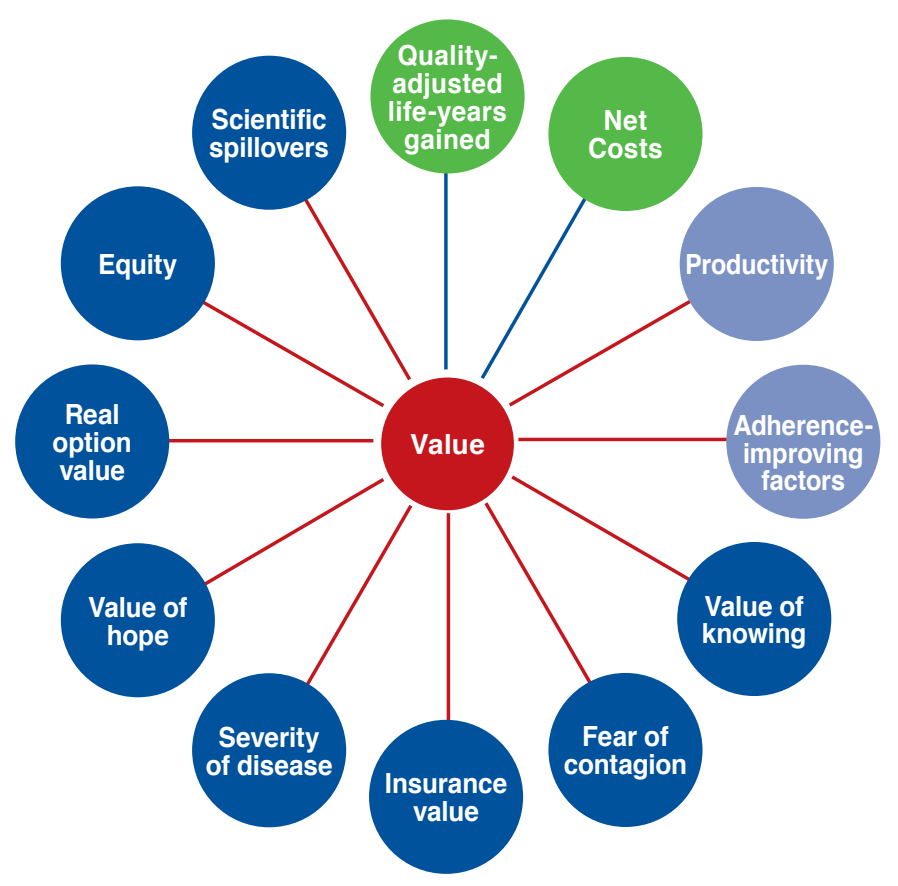

Core elements of value

- Common but consistently used elements of value

- Potential novel elements of value

- Value element in traditional payer perspective

— Value element also included in societal perspective

Adapted from Lakdawalla DN, Doshi JA, Garrison LP Jr, Phelps CE, Basu A, Danzon PM. Defining elements of value in health care - a health economics approach: an ISPOR Special Task Force report [3].36

lifetime treatment) ${ }^{27}$ voretigene neparvovec for inherited blindness (\$644K per QALY), ${ }^{28}$ ivacaftor for cystic fibrosis with gating mutation (\$957K per QALY), ${ }^{29}$ and C inhibitors (Cinryze and Haegarda) for hereditary angioedema (\$5,954K per QALY and $\$ 328 \mathrm{~K}$ per QALY, respectively). ${ }^{30}$ Nusinersen (Spinraza) for spinal muscular atrophy (SMA) is projected to cost $\$ 750 \mathrm{~K}$ for the first year and $\$ 375 \mathrm{~K}$ per year for the following years. ${ }^{31}$ On the other hand, some one-time therapies, such as tisagenlecleucel for B-cell acute lymphoblastic leukemia are projected to have a substantial upfront cost but a relatively low incremental cost-effectiveness ratio- $\$ 46 \mathrm{~K}$ per QALY.32 Organ transplants are another treatment with high upfront costs for long-term benefit, but with surprisingly few published cost-effectiveness assessments. ${ }^{33}$

\section{Assessing Value for Gene Therapies:}

\section{Moving Beyond the QALY}

Different health systems are clearly applying a higher CET for ultrarare, health-catastrophic conditions. A large majority of the participants in a NICE Citizen Council on the Rule of Rescue cited "exceptional circumstances" in this instance. ${ }^{34}$ ICER makes allowance for "other benefits and contextual considerations" but qualitatively as a checklist-not by an explicit mathematical formula. ${ }^{8}$

A recent International Society for Pharmacoeconomics and Outcomes Research (ISPOR) Special Task Force (STF) on U.S. Value Frameworks stated, "Health plan coverage and reimbursement decisions should consider cost-effectiveness analyses, as measured by cost per QALY, as a starting point" and recommended further:

Elements of costs and benefits not normally included in cost-effectiveness analysis that affect individual well-being (such as severity of illness, equity, and risk protection) may be relevant for some health plan decisions; however, more research is needed on how best to measure and include them in decision making. ${ }^{35}$

Figure 1, adapted from that ISPOR STF report, identifies many potential elements, including several related to the uncertainty individuals face in insurance and medical care purchases. $^{36,37}$ These additional elements, we would argue, provide an economic rationale for defining a higher CET for proven life-saving therapies for ultrarare, health-catastrophic conditions, as has also been sketched in a blog by Jena and Lakdawalla (2017). ${ }^{38}$ The "insurance value" element is key to this. It has 2 components to risk protection: financial and health. Ultrarare conditions sometimes involve both financial and health catastrophe. In terms of financial risk protection, risk-averse individuals would be willing to pay a premium above the expected cost of treatment. Intuitively, the size of this premium would increase with the size of the potential financial and health loss. This alone would suggest a higher CET when anchored to the QALY.

However, this is compounded in at least 2 other ways by the health catastrophe. The STF report also cites "severity of disease" as an element to consider. Since the utility scale ( 0 to 1 ) as reflected in the QALY assumes that a gain from 0.6 to 0.8 is equivalent to a gain from 0.2 to 0.4 , it does not adjust for the latter, greater baseline severity of disease. Qualitative survey research in general populations suggests not all QALY gains are considered equal: people would generally give priority to subpopulations with poor baseline health, including those at end of life. ${ }^{39,40}$

Three other uncertainty-related elements are also pertinent. ${ }^{36,37}$ First, "real option value" is the notion in which therapies that extend life create value by providing an option for patients to benefit from future innovative therapies. Thus, patients would be willing to pay more for QALYs in a disease area with better long-term prospects. For lifetime cures (rather than a sequence of multiple lines of therapies, as is common in oncology), this would be less of a factor because the projection of a normal life expectancy should, in theory, take into account 
general gains across all conditions. Modeling practice is not usually this precise and may underestimate this potential gain. A second uncertainty-related element has been called the "value of hope."11 Interventions that result in a significant share of "cures" (i.e., long-term survivors) could create value for patients who would be willing to pay more to have this option even if the 2 therapies had identical expected QALYs. Third, the "value of knowing" is reduced uncertainty about response to an intervention. The combination of these several elements would support a higher CET for ultrarare, health-catastrophic diseases. The STF report recommends further research to estimate and value these elements under 2 alternative aggregation approaches—net monetary benefit (i.e., cost-benefit analysis) or multicriteria decision analysis. ${ }^{35}$

Jena and Lakdawalla also point out the relevance of several other elements in this situation: health equity (related to severity of disease), caregiver burden, and family spillovers (in terms of the negative effect on the well-being of family members). ${ }^{38}$ "Equity" is also listed as an element and is frequently cited in these discussions of rare diseases. ${ }^{26,42}$ However, as Culyer (2015) has emphasized, there are multiple concepts of equity that will require trade-offs among them. ${ }^{43}$

Considering all of these elements, if a health plan were to use only a single QALY-based CET for all new technologies, it might reject interventions for ultrarare, health-catastrophic conditions that their enrollees would be happy to fund. It is important to note that if additional, previously unrecognized value-creating elements are identified and accounted for separately, given a fixed annual budget, this would reduce the share attributable to the QALY gain itself and, hence, the average willingness to pay for the pure QALY gains. ${ }^{44}$

\section{Case Exemplar: SMA}

HTA bodies have used higher thresholds for rare, catastrophic diseases, presumably representing the wishes of their enrollees to pay more for health gains in these situations. This willingness will be tested even further with the emergence of numerous one-time gene therapies that are in the industry pipeline. ${ }^{2}$ A good example of the impending challenge is a promising gene therapy for SMA- a rare, severe neuromuscular disease caused by a genetic defect leading to a progressive loss of motor neurons. It is estimated that approximately 300 babies are born each year in the United States with SMA type 1-a rapid, progressive, highly morbid, and fatal rare disease. ${ }^{45} \mathrm{~A}$ natural history study of SMA type 1 found that $90 \%$ of patients will either die by age 2 or require $\geq 16$ hours per day of ventilation. ${ }^{46}$ A gene replacement therapy in development for SMA type 1 provides an exemplar for valuation challenges. ${ }^{47,48}$

But even this example and projection are somewhat speculative given the inevitable lack of long-term data at launch supporting benefit for a full lifetime. For reasons of biology and mechanism of action, however, it is not unreasonable to consider this as a possible scenario. If the value of a life is on the order of millions of dollars, how will such an amount be financed in the fragmented U.S. health insurance system that operates on an annual budgetary basis? There is no consensus on how to address this recognized challenge.

Even based on ICER's value-based threshold of $\$ 150 \mathrm{~K}$ per QALY, ranging up to $\$ 500 \mathrm{~K}$, and the value of a healthy lifetime of, say, 30.5 (discounted life-years) would imply a range of $\$ 4.5 \mathrm{M}$ to $\$ 15.5 \mathrm{M}$ per life. The U.S. government's mean estimated VSL falls in this range. Other benchmarks and analogs (Table 1) suggest multimillion-dollar valuations per life saved. The current standard of care for SMA type 1 is nusinersen, costing $\$ 750 \mathrm{~K}$ for the first year and then $\$ 375 \mathrm{~K}$ annually thereafter (not counting the costs of repeated intrathecal administrations)

Clearly, these valuations for one-time, potentially curative, gene therapies would result in high per-patient costs. To address concerns about value and affordability, various financing programs are being discussed, including installment payments, outcomes-based agreements, or reinsurance to address the durability issue. ${ }^{49}$ But even with these costs being within accepted norms for CETs, payers and policymakers may not be administratively prepared to finance these emerging groundbreaking therapies.

\section{Conclusions}

Numerous gene therapies are currently in development aiming to address the underlying root cause of genetic diseases. It is imperative we find a consensus on how to appropriately reward value created by these gene therapies to incentivize appropriate risk taking and investments by their developers: a higher CET would, by economic logic, support a higher VBP and, thus, a higher reward. If consensus on appropriate rewards cannot be found for safe and effective gene therapies for diseases such as SMA with clear criticality and unmet need, it will be even more difficult to do so for diseases where the value provided is less apparent.

\section{Authors}

LOUIS P. GARRISON, PhD, The Comparative Health Outcomes, Policy, and Economics (CHOICE) Institute, University of Washington School of Pharmacy, Seattle. TRISTEN JACKSON, PharmD, MS, and DOUGLAS PAUL, PharmD, PhD, Medical Marketing Economics (MME) and University of Mississippi, Oxford, Mississippi. MIKE KENSTON, BS, MBA, Independent Consultant, Libertyville, Illinois.

AUTHOR CORRESPONDENCE: Louis P. Garrison, PhD, Professor Emeritus, The Comparative Health Outcomes, Policy, and Economics (CHOICE) Institute, University of Washington, 1959 NE Pacific St., Box 357630, Seattle, WA 98195. Tel.: 206.427.0798;

E-mail: lgarrisn@u.washington.edu. 


\section{DISCLOSURES}

Funding for the writing of this article was provided by AveXis Pharmaceuticals, which reviewed the manuscript and contributed feedback during manuscript development. The authors had final editorial control. Jackson and Paul are employees of MME, a biopharmaceutical consulting firm that received funding from AveXis for work on this project. Jackson and Paul also report consulting fees from numerous other biopharmaceutical companies outside of this project. Garrison reports consulting fees from AveXis for work on this project and advisory/consultancy fees from BioMarin, Roche, Novartis, and Pfizer unrelated to this project. Kenston is a former employee of AveXis and reports consulting fees from AveXis for this project and for other projects outside of this work.

\section{REFERENCES}

1. Danzon PM. Affordability challenges to value-based pricing: mass diseases, orphan diseases, and cures. Value Health. 2018;21(3):252-57.

2. Marsden G, Towse A, Pearson SD, Dreitlein B, Henshall C. Gene therapy: understanding the science, assessing the evidence, and paying for value. A report from the 2016 ICER Membership Policy Summit. March 2017. Available at: https://icer-review.org/wp-content/uploads/2017/03/ICER-GeneTherapy-White-Paper-030317.pdf. Accessed January 23, 2019.

3. Neumann PJ, Sanders GD, Russell LB, Siegel JE, Ganiats TG, eds. CostEffectiveness in Health and Medicine. 2nd ed. New York: Oxford University Press; 2016.

4. Hirth RA, Chernew ME, Miller E, Fendrick AM, Weissert WG Willingness to pay for a quality-adjusted life year: in search of a standard. Med Decis Making. 2000;20(3):332-42.

5. Ubel PA, Hirth RA, Chernew ME, Fendrick AM. What is the price of life and why doesn't it increase with inflation? Arch Int Med. 2003;163(14):1637-41

6. Grosse SD. Assessing cost-effectiveness in healthcare: history of the $\$ 50,000$ per QALY threshold. Expert Rev Pharmacoecon Outcomes Res. 2008;8(2):165-78.

7. Neumann PJ, Cohen JT, Weinstein MC. Updating cost-effectivenessthe curious resilience of the \$50,000-per-QALY threshold. N Engl J Med. 2014;371(9):796-97.

8. Institute for Clinical and Economic Review. Overview of the ICER value assessment framework and update for 2017-2019. January 2018. Available at: https://icer-review.org/wp-content/uploads/2018/03/ICER-value-assessmentframework-update-FINAL-062217.pdf. Accessed January 23, 2019.

9. Wyld M, Morton RL, Hayen A, Howard K, Webster AC. A systematic review and meta-analysis of utility-based quality of life in chronic kidney disease treatments. PLoS Med. 2012;9(9):e1001307.

10. United States Renal Data System. 2017 ADR chapters. Reference tables, volume 2: ESRD. Table K. 2017. Available at: https://www.usrds.org/2017/ view/Default.aspx. Accessed January 23, 2019.

11. Garber AM, Phelps CE. Economic foundations of cost-effectiveness analysis. J Health Econ. 1997;16(1):1-31.

12. World Health Organization Commission on Macroeconomics and Health. Macroeconomics and health: investing in health for economic development. December 20, 2001. Available at: http://www.who.int/iris/ handle/10665/42435. Accessed January 23, 2019.

13. Robinson L, Hammitt J, Chang AY, Resch S. Understanding and improving the one and three times GDP per capita cost-effectiveness thresholds. Health Policy Plan. 2017;32(1):141-45.

14. World Bank. World Development Indicators. PPP (current international \$). Database. July 1, 2017. Available at: https://data.worldbank.org/indicator/ NY.GDP.PCAP.CD?end=2017\&start=2016. Accessed January 23, 2019.

15. Claxton K, Martin S, Soares M, et al. Methods for the estimation of the NICE cost-effectiveness threshold: revised report following referees comments. June 10, 2013. Available at: https://www.york.ac.uk/media/che/documents/reports/resubmitted_report.pdf. Accessed January 23, 2019.
16. Woods B, Revill P, Sculpher M, Claxton K. Country-level cost-effectiveness thresholds: initial estimates and the need for further research. Value Health. 2016;19(8):929-35.

17. Institute for Clinical and Economic Review. Modifications to the ICER value assessment framework for treatments for ultra-rare diseases. November 2017. Available at: https://icer-review.org/wp-content/uploads/ 2017/11/ICER-Adaptations-of-Value-Framework-for-Rare-Diseases.pdf. Accessed January 23, 2019

18. National Institute for Health and Care Excellence. Interim process and methods of the highly specialised technologies programme update to reflect 2017 changes. April 2017. Available at: https://www.nice.org.uk/ Media/Default/About/what-we-do/NICE-guidance/NICE-highly-specialisedtechnologies-guidance/HST-interim-methods-process-guide-may-17.pdf. Accessed January 23, 2019.

19. Bosworth RC, Hunter A, Kibria A; STRATA. The value of a statistical life: economics and politics. March 2017. Available at: https://strata.org/pdf/2017/ vsl-full-report.pdf. Accessed January 23, 2019.

20. Viscusi WK, Aldy JE. The value of a statistical life: a critical review of market estimates throughout the world. J Risk Uncertainty. 2003;27(1):5-76.

21. U.S. Office of Management and Budget. Circular A-4. September 17, 2003. Available at: https://obamawhitehouse.archives.gov/omb/circulars_ a004_a-4/. Accessed January 23, 2019.

22. U.S. Department of Health and Human Services, Office of the Assistant Secretary for Planning and Evaluation. Guidelines for regulatory impact analysis. 2016. Available at: https://aspe.hhs.gov/pdf-report/guidelines-regulatory-impact-analysis. Accessed January 23, 2019.

23. Moran MJ, Monje C. Guidance on treatment of the economic value of a statistical life (VSL) in U.S. Department of Transportation analyses-2016 adjustment. August 8, 2016. Available at: https://www.transportation. gov/sites/dot.gov/files/docs/2016\%20Revised\%20Value\%20of\%20a\%20 Statistical\%20Life\%20Guidance.pdf. Accessed February 5, 2019

24. Viscusi WK. Best estimate selection bias in the value of a statistical life J Benefit Cost Anal. 2018;9(2):205-46

25. Viscusi WK. Reference-dependence effects in benefit assessment: beyond the WTA-WTP dichotomy and WTA-WTP ratios. J Benefit Cost Anal. 2015;6(1):187-206.

26. Cookson R, Mirelman AJ, Griffin S, et al. Using cost-effectiveness analysis to address health equity concerns. Value Health. 2017;20(2):206-12.

27. Institute for Clinical and Economic Review. Emicizumab for hemophilia A with inhibitors: effectiveness and value. Final evidence report. April 16, 2018. Available at: https://icer-review.org/wp-content/uploads/2017/08/ ICER_Hemophilia_Final_Evidence_Report_041618.pdf. Accessed January 23, 2019.

28. Institute for Clinical and Economic Review. Voretigene neparvovec for biallelic RPE65-mediated retinal disease: effectiveness and value. Final evidence report. February 15, 2018. Available at: https://icer-review.org/ wp-content/uploads/2017/06/MWCEPAC_VORETIGENE_EVIDENCE_ REPORT_01122018-1.pdf. Accessed January 23, 2019.

29. Institute for Clinical and Economic Review. Modulator treatments for cystic fibrosis: effectiveness and value. Evidence report. May 3, 2018. Available at: https://icer-review.org/wp-content/uploads/2017/10/CF_ Evidence_Report_05222018.pdf. Accessed January 23, 2019.

30. Institute for Clinical and Economic Review. Prophylaxis for hereditary angioedema with lanadelumab and $\mathrm{Cl}$ inhibitors: effectiveness and value. Final evidence report. November 15, 2018. Available at: https:// icer-review.org/wp-content/uploads/2018/03/ICER_HAE_Final_Evidence_ Report_111518.pdf. Accessed January 23, 2019

31. Wolters Kluwer. Medi-Span Price Rx Online. Database. 2018. Available at: https://www.wolterskluwercdi.com/price-rx/. Accessed January 23, 2019. 
32. Institute for Clinical and Economic Review. Chimeric antigen receptor T-cell therapy for B-cell cancers: effectiveness and value. Final evidence report. March 23, 2018. Available at: https://icer-review.org/wp-content/ uploads/2017/07/ICER_CAR_T_Final_Evidence_Report_032318.pdf. Accessed January 23, 2019.

33. Bentley TS, Phillips SJ. Milliman research report: 2017 US organ and tissue transplant cost estimates and discussion. August 2017. Available at: http://www.milliman.com/uploadedFiles/insight/2017/2017-TransplantReport.pdf. Accessed January 23, 2019.

34. National Institute for Health and Care Excellence. Citizen's Council Report: Rule of Rescue. January 2006. Available at: https://www. nice.org.uk/Media/Default/Get-involved/Citizens-Council/Reports/ CCReport06RuleOfRescue.pdf. Accessed January 23, 2019.

35. Garrison LP, Neumann PJ, Willke RJ, et al. A health economics approach to US value assessment frameworks-summary and recommendations of the ISPOR Special Task Force report [7]. Value Health. 2018;21(2):161-65.

36. Lakdawalla DN, Doshi JA, Garrison LP Jr, Phelps CE, Basu A, Danzon PM. Defining elements of value in health care-a health economics approach: an ISPOR Special Task Force report [3]. Value Health. 2018;21(2):131-39.

37. Garrison Jr LP, Kamal-Bahl S, Towse A. Toward a broader concept of value: identifying and defining elements for an expanded cost-effectiveness analysis. Value Health. 2017;20(2):213-16.

38. Jena AB, Lakdawalla DN. Value frameworks for rare diseases: should they be different? Health Affairs Blog: Drugs and Innovation. April 12, 2017. Available at: https://www.healthaffairs.org/do/10.1377/ hblog20170412.059563/full/. Accessed January 23, 2019.

39. Nord E. Severity of illness versus expected benefit in societal evaluation of healthcare interventions. Expert Rev Pharmacoeconomics Outcomes Res. 2001;1(1):85-92.

40. National Institute for Health and Clinical Excellence. Appraising lifeextending, end of life treatments. July 2009. Available at: https://www.nice. org.uk/guidance/GID-TAG387/documents/appraising-life-extending-end-oflife-treatments-paper2. Accessed January 23, 2019.
41. Lakdawalla DN, Romley JA, Sanchez Y, Maclean JR, Penrod JR, Philipson T. How cancer patients value hope and the implications for cost-effectiveness assessments of high-cost cancer therapies. Health Aff (Millwood). 2012;31(4):676-82.

42. Ollendorf DA, Chapman RH, Pearson SD. Evaluating and valuing drugs for rare conditions: no easy answers. Value Health. 2018;21(5):547-52.

43. Culyer T. Equity and efficiency. Presentation at: ISPOR 5th Latin America Conference; September 7, 2015; Santiago, Chile. Available at: https://www.ispor.org/docs/default-source/presentations/385. pdf?sfvrsn=6f1071d4_1. Accessed January 23, 2019.

44. Danzon PM, Drummond MF, Towse A, Pauly MV. Objectives, budgets, thresholds, and opportunity costs - a health economics approach: an ISPOR special task force report [4]. Value Health. 2018;21(2):140-45.

45. Verhaart IEC, Robertson A, Wilson IJ, et al. Prevalence, incidence and carrier frequency of 5q-linked spinal muscular atrophy-a literature review. Orphanet J Rare Dis. 2017;12(1):124.

46. Finkel RS, McDermott MP, Kaufmann P, et al. Observational study of spinal muscular atrophy type I and implications for clinical trials. Neurology. 2014;83(9):810-17.

47. Mendell JR, Al-Zaidy S, Shell R, et al. Single-dose gene-replacement therapy for spinal muscular atrophy. N Engl J Med. 2017;377(18):1713-22.

48. Lopes JM. Zolgensma (AVXS-101) under priority FDA review as possible gene therapy for SMA type 1. SMA News Today. December 4, 2018. Available at: https://smanewstoday.com/2018/12/04/zolgensma-avxs-101-under-priority-fda-review-as-possible-gene-therapy-for-sma-type-1/. Accessed January 23, 2019.

49. Yeung K, Suh K, Basu A, Garrison LP, Bansal A, Carlson JJ. Paying for cures: how can we afford it? Managed care pharmacy stakeholder perceptions of policy options to address affordability of prescription drugs. J Manag Care Spec Pharm. 2017;23(10):1084-90. Available at: https://www.jmcp.org/ doi/10.18553/jmcp.2017.23.10.1084. 